\title{
Sources, nature, and fate of heavy metal-bearing particles in the sewer system
}

\author{
J. HOUHOU ${ }^{*}$, B.S. LARTIGES ${ }^{1 *}$, E. MONTARGES-PELLETIER ${ }^{1}$, \\ J. SIELIECHI ${ }^{3}$, J. GHANBAJA ${ }^{2}$, A. KOHLER ${ }^{2}$
}

${ }^{1}$ Nancy University - LEM-ENSG/INPL-CNRS, Pôle de l'Eau, 15 Avenue du Charmois, BP 40 54501 Vandouvre Cedex, FRANCE

${ }^{2}$ Nancy University - SCMEM-FST/UHP, 7137 boulevard des Aiguillettes, BP 239 54506 Vandoeuvre Cedex, FRANCE

${ }^{3}$ University of Ngaoudere - ENSAI-IUT, P.O. Box 455, Ngaoundere, CAMEROON.

E-mail : jamil.houhou@hotmail.fr bruno.lartiges@get.omp.eu

(*) To whom correspondence should be addressed 


\section{ABSTRACT}

A preliminary insight into metal cycling within the urban sewer was obtained by determining both the heavy metals concentrations $(\mathrm{Cu}, \mathrm{Zn}, \mathrm{Pb}, \mathrm{Cd}, \mathrm{Ni}, \mathrm{Cr})$ in sewage and sediments, and the nature of metal-bearing particles using TEM-EDX, SEM-EDX and XRD. Particles collected from tap water, sump pit deposits, and washbasin siphons, were also examined to trace back the origin of some mineral species. The results show that the total levels in $\mathrm{Cu}, \mathrm{Pb}$, $\mathrm{Zn}, \mathrm{Ni}$, and $\mathrm{Cr}$ in sewage are similar to that reported in the literature, thus suggesting that a time-averaged heavy metal fingerprint of domestic sewage can be defined for most developed cities at the urban catchment scale. Household activities represent the main source of $\mathrm{Zn}$ and $\mathrm{Pb}$, the water supply system is a significant source of $\mathrm{Cu}$, and in our case, groundwater infiltration in the sewer system provides a supplementary source of $\mathrm{Ni}$ and $\mathrm{Cd}$. Concentrations in heavy metals were much higher in sewer sediments than in sewage suspended solids, the enrichment being due to the preferential settling of metal-bearing particles of high density and/or the precipitation of neoformed mineral phases. TEM and SEM-EDX analyses indicated that suspended solids, biofilms, and sewer sediments contained similar heavy metal-bearing particles including alloys and metal fragments, oxidized metals and sulfides. Copper fragments, metal carbonates $(\mathrm{Cu}, \mathrm{Zn}, \mathrm{Pb})$, and oxidized soldering materials are released from the erosion of domestic plumbing, whereas the precipitation of sulfides and the sulfurization of metal phases occur primarily within the household connections to the sewer trunk. Close examination of sulfide phases also revealed in most cases a complex growth history recorded in the texture of particles, which likely reflects changes in physicochemical conditions associated with successive resuspension and settling of particles within the sewer system.

Keywords: Sewer system, heavy metal, sulfide, electron microscopy. 


\section{INTRODUCTION}

The significance of heavy metal sources to the sewer system has generally been assessed in terms of total loads (Wilkie et al. 1996; Gray and Becker 2002; Sörme and Lagverkist 2002; Palmquist and Hanaeus 2005; Rule et al. 2006; Gasperi et al. 2008). However, once in the sewer, soluble and particulate heavy metals may undergo significant physicochemical modifications such as precipitation as sulfide or phosphate minerals, or sulfurization of metal alloys in anaerobic conditions (Chebbo et al. 2001; El Samrani et al. 2004). Part of heavy metals transported in sewage is thus stored within sewer sediments during dry weather (El Samrani et al. 2004). In combined sewers, those sediments are eroded during rainy events (Vollertsen and Hvitved-Jacobsen, 2000; Rocher et al., 2004), and upon overflows, may contribute up to $50 \%$ of the total load of metal contaminants discharged to the receiving waters (Gromaire et al. 2001). Sulfide neoformed species were even shown to represent the main heavy metal-bearing particles at the peak flow rate during sewer overflows (El Samrani et al. 2004). An improved understanding of heavy metal cycling in the sewer system is then required to evaluate such metal accumulation in sewer sediments, and hence the pollution issued from combined sewer overflows.

Identifying the sources of heavy metals and determining their fate in the sewer system also represent an important step toward a sustainable management of primary and secondary sludges produced at the wastewater treatment plant (Boller 1997). Primary sludges are generally disposed of to landfill, which practice is considered unsustainable. On the other hand, the application of secondary sludges to agricultural land as soil amendment is primarily limited by their metals contents (e.g. Singh and Agrawal 2008). A control at the source of heavy metals entering the sewer system would certainly help to comply with increasingly stringent environmental regulations on sludge disposal (Balmer 2001). A better knowledge of the nature of heavy metal-bearing particles transported in wastewater could also be useful to develop new disposal strategies not only for primary sludges, but also for sediments retained in the sewer (Ashley et al. 2000), and for sludges generated during the physicochemical treatment of combined sewer overflows (El Samrani et al. 2008).

As detailed information regarding the speciation of heavy metals in the urban sewer is lacking, this study was undertaken to determine both the metal concentrations and the nature of heavy metal-bearing particles in various compartments of the sewer system, i.e. sewage suspended solids, biofilms, and sediments. Particles collected from tap water, sump pit deposits, and washbasin siphons, were also examined to trace back the origin of some mineral 
species. The speciation was carried out by Transmission (TEM) and Scanning (SEM) electron microscopies coupled with energy-dispersive X-ray spectrometry. Such techniques provide combined data on both direct identification of the mineralogy and the texture of heavy metalbearing particles down to the nanoscale (El Samrani et al. 2004).

\section{EXPERIMENTAL SECTION}

2.1 Sample collection and preparation. Samples were taken from Grand Nancy sewer system between November 2004 and October 2006. Grand Nancy is an urban community of about 270000 inhabitants located in north-eastern France. The sewage collecting system comprises $1200 \mathrm{~km}$ of pipes, $250 \mathrm{~km}$ of them being man-entry sewer (pipe diameter $\geq 1.2 \mathrm{~m}$ ). The central core of Greater Nancy is served by a combined sewer, whereas the peripheral areas are drained by separate systems. Three sewer sections, each with 5 sampling sites from upstream to downstream of the sewer network, were selected to represent the various land uses in the urban community (residential, commercial, industrial, high school, and hospital). A detailed description of these sampling sites has been provided in a previous publication (Houhou et al. 2009). On a general basis, the upstream sampling sites only receive domestic sewage from a separate sewer, the following sampling sites are impacted by wastewaters originating either from hospital, commercial or industrial areas, whereas the downstream sampling sites mainly convey sewage from high density residential areas and small businesses through a combined sewer. A restricted access to the sewer limited our sampling to weekdays.

Grab-samples of sewage (65 samples) were collected through open manholes using a polyethylene bucket, bacterial biofilms (10 samples) were scraped from pipes wall, whereas sewer sediments were scooped with a $1 \mathrm{~L}$ cup mounted on a telescopic handle. All sediments were collected from residential areas. Various categories of sewer sediment have been described in the literature: according to Crabtree (1989) and Chebbo (2001), the collected sediments correspond to type A coarse granular deposits. In order to identify potential sources of heavy metal pollutants, a few samples were also taken from local aquifers through piezometers (Houhou et al. submitted), drinking water taps (10 samples from 3 houses collected with the tap fully opened), washbasins siphons (8 samples from 6 houses), and sump-pits (3 samples from 3 houses). Sewage, tapwater, and groundwater, were filtered through pre-washed $0.22 \mu \mathrm{m}$ pore size cellulose acetate membrane (Chromafil CA-20/25), and the filtrates were stored in $65 \mathrm{~mL}$ polyethylene bottles at $4{ }^{\circ} \mathrm{C}$ until analysis.

Slime deposits from washbasin siphons and sewer biofilms were freeze-dried. Suspended matter from sewage was also freeze-dried after centrifugation at $15000 \mathrm{~g}$ for 30 
min (Sorvall ${ }^{\circledR}$ Evolution RC). Sewer sediments were sieved to obtain size fractions of (I) $<50$ $\mu \mathrm{m}$, (II) $50-250 \mu \mathrm{m}$, and (III) $250 \mu \mathrm{m}-2 \mathrm{~mm}$. In order to concentrate heavy mineral phases, a few milligrams of freeze-dried sediment fractions were subjected to a heavy-liquid bromoform separation (density $=2.9$ ) assisted by centrifugation $(50 \mathrm{~mL}$ teflon tube centrifuged at $4000 \mathrm{rpm}$ for $20 \mathrm{~min}$ ). The heavy fraction was then retrieved and dried under hood overnight.

2.2 Chemical analyses and identification of heavy metal-bearing particles. Soluble heavy metal concentrations were measured on $\mathrm{HNO}_{3}$ acidified samples using a Perkin-Elmer ELAN 6000 ICP-MS (Inductively Coupled Plasma Mass Spectrometry). Freeze-dried solid fractions were first ground with an agate microcrusher to reach a particle size less than $50 \mu \mathrm{m}$. A 200 mg aliquot was then melted with $600 \mathrm{mg} \mathrm{LiBO}_{3}$ in a Pt-Au crucible, and dissolved with $1 \mathrm{~N}$ $\mathrm{HNO}_{3}$. The resulting solution was analyzed by ICP-MS (Carignan et al. 2001).

X-ray diffractograms from powder samples were recorded with a D8 Bruker diffractometer using a Co $\mathrm{K}_{\alpha 1}$ radiation at $\lambda=1.788965 \AA$. The diffractometer is equipped with a $(\theta, 2 \theta)$ goniometer and a position sensitive detector. Reflexions were collected in ambient conditions within the $\left[3-65^{\circ}\right] 2 \Theta$ range, with a step width of $0.036^{\circ}$ and a $3 \mathrm{~s}$ collecting time.

Direct speciation of heavy metal-bearing particles was carried out using a Philips CM20 Transmission Electron Microscopy (TEM) $(200 \mathrm{kV})$ coupled with an EDAX energy dispersive X-ray spectrometer (EDX), and a Hitachi 54800 Scanning Electron Microscopy (SEM) equipped with a Kevex 4850-S EDX. EDXS yields an elemental analysis of individual particles from freeze-dried solids. Stoichiometric ratios can then be calculated from atomic percentages given by EDX spectra, and compared with known mineralogical compositions. For TEM imaging and microanalysis, the powder sample was re-suspended in ethanol under ultrasonication, and a drop of suspension was evaporated on a carbon-coated copper grid (EuroMEDEX, Mesh200). A spot size of about $70 \mathrm{~nm}$ was used to record EDX spectra with a counting time of 40 seconds. EDX calibration standards were run to obtain quantitative analyses of major and trace elements with a detection limit of about $100 \mathrm{ppm}$.

Samples for SEM-EDX examination were sprinkled onto $2 \mathrm{~cm}^{2}$ plates and carbon coated. Backscattered electron imaging (BEI) was used to locate the particles of interest. In that mode, brightness is related to the average atomic number of materials, and the heavy mineral phases appear as bright spots that can be easily detected within the organic matrix of 
samples such as biofilms or sewage suspended matter. In order to increase the emission of backscattered electrons, the SEM microscope was generally operated with a beam current of 3 $\mathrm{pA}$ and an accelerating voltage of $20 \mathrm{kV}$ (analysed microvolume of about $6 \mu \mathrm{m}^{3}$ ). However, to improve the quantification of low atomic number elements, EDX analysis was sometimes carried out at an accelerating voltage of $10 \mathrm{kV}$ (sampling volume of $3 \mu \mathrm{m}^{3}$ ).

\section{RESULTS AND DISCUSSION}

\subsection{Heavy metal contents in the sewer system.}

3.1.1 Total and soluble heavy metal concentrations in sewage. The average concentrations, standard deviations, and ranges in dissolved and total metal concentrations in Nancy wastewater are given in table 1. As in most previous studies (e.g. Wilkie et al. 1996), the measured heavy metal concentrations in sewage are highly variable, each standard deviation being equivalent to the mean value in our case. Such variability, classically attributed to the diversity of inputs to the sewer system (Wilkie et al. 1996), may also reflect the complex dynamics of that bio-physico-chemical reactor. Though our sampling only captured weekdays, the mean total levels of $\mathrm{Cu}, \mathrm{Pb}, \mathrm{Zn}, \mathrm{Ni}$, and $\mathrm{Cr}$, were very similar to those found for domestic sewage collected in various cities, i.e. Melbourne (Wilkie et al. 1996), Stockholm (Palmquist and Hanaeus 2005), Milwaukee (Soonthornnonda and Christensen 2008), and Yokosuka City (Chino et al. 1991) (see Table 1). This suggests that (i) the discharge of domestic sewage in Grand Nancy urban sewer largely dominates the contribution of industrialized and commercial areas; (ii) the globalization of consumer behaviors and the standardization of construction materials tend to achieve a time-averaged heavy metal fingerprint of domestic sewage in developed cities at the urban catchment scale, since additional local influences such as age and type of neighbourhood, or hardness of local tap water, may modify the load of metals entering the sewer system (Comber and Gunn 1996; Rule et al. 2006). Moreover, in Grand Nancy, the heavy metal loads were higher (up to 1.9 more for $\mathrm{Cu}$ and $\mathrm{Zn}$ ) in peripheral areas using a tight separate sewer system.

As shown in fig. 1a, the dissolved load of a given heavy metal is comparable with that of the corresponding particulate component. Even though a conservative behavior is not expected for the soluble metals investigated, the approximate contribution of various possible sources was nevertheless considered by determining the average dissolved concentrations in $\mathrm{Ni}, \mathrm{Cu}, \mathrm{Al}, \mathrm{Zn}, \mathrm{Pb}$, and $\mathrm{Cd}$, in groundwater, drinking water, wastewater, and domestic sewage 
(fig. 1b). Domestic sewage refers to samples taken in separate sewer sections where no groundwater infiltration could be evidenced by water stable isotope studies (Houhou et al. submitted), whereas wastewater represents all sewage samples collected in this study. Hence, the heavy metal contents in wastewater are generally lower than those in domestic sewage because of dilution by extraneous flows. A notable exception is soluble $\mathrm{Ni}$ that mainly originates from those clear waters entering the sewer system. In our case, Ni is released from the weathering of organic matter contained in Toarcian shales (Grosjean et al. 2004), which form the main geological outcrop in Nancy urban watershed. Other metals such as Co and U, and to a lesser extent $\mathrm{Cr}$ and $\mathrm{Cd}$, were found to follow the same pattern as $\mathrm{Ni}$ (fig. 1b).

A significant amount of dissolved copper contained in sewage $(33.2 \pm 22.2 \mu \mathrm{g} / \mathrm{l})$ comes from drinking water $(14.2 \pm 6.1 \mu \mathrm{g} / \mathrm{l})$. This is in accordance with previous literature indicating that the elevated $\mathrm{Cu}$ concentration in tap water can be assigned to the corrosion of domestic plumbing system (Oskarsson and Norrgren, 1998; Merkel et al. 2002; Tamasi and Cini, 2004). The pattern displayed by $\mathrm{Al}$ is similar, the concentration in drinking water corresponding to the residual aluminium from alum coagulation of raw surface water at the treatment facility.

In contrast, dissolved $\mathrm{Zn}$ and $\mathrm{Pb}$ reveal an obvious anthropic contribution, the average concentration of those heavy metals in sewage being much higher than in drinking water and in groundwater. The main sources of $\mathrm{Zn}$ have been shown to be predominantely household agents (food, tap water, laundry detergent) and personal-care products (toothpaste, shampoo) (Sörme and Lagerkvist 2002; Tsuji-Naito et al., 2007). According to Gray and Becker (2002), bathroom contributes to about $73 \%$ of the $\mathrm{Zn}$ load in domestic sewage, whereas laundry greywater is the main $\mathrm{Pb}$ source in sewage (about $81 \%$ of the $\mathrm{Pb}$ load). However, SEMEDXS examination of Polyvinyl chloride pipes used for wastewater evacuation (Houhou, unpublished results), revealed the presence of numerous $\mathrm{PbO}$ micron-size particles that may release some lead by chelation with microbially produced organic acids (Francis and Dodge, 1986). The potential sources of Cd remain rather ill-defined: according to Aonghusa and Gray (2002) detergents account for $32 \%$ of the Cd load in Irish municipal wastewater, whereas Gray and Becker (2002) indicate that dissolved cadmium can result from different household activities such as kitchen (27.5\%), laundry (16.5\%), bathroom (39.5\%), and toilet (16.5\%). Our results also suggest that the input of Cd from clear waters should not be neglected (fig. 1b). 
3.1.2 Heavy metal loads in suspended matter, sewer sediments, and sump pit deposits. Table 2 shows the metal contents found in suspended solids, sewer sediments (fraction I, II and III) and sump pit deposits. The heavy metal profile is similar in sewage suspended matter and sump pit deposits, with contents slightly higher in the latter. In contrast, significant enrichments in heavy metal concentrations can be evidenced between sediments I and sewage suspended solids. Depending on the element considered, the heavy metals contents in sediments $\mathrm{I}$ are 3 to 17 times higher than those measured in suspended solids. Such enrichment may be due to the preferential settling of high-density metal-bearing particles and/or to the precipitation and change in metal speciation within the sewer system during transport (Gromaire et al. 2001; El Samrani et al. 2004). Except for Zn and Cd, no significant differences in heavy metal contents are observed between sediments I and II, while sediments III are slightly impoverished in those elements with metal contents 3 to 6 times lower. The higher heavy metal concentrations in finer sediments, consistent with previous studies (Chebbo et al. 2001; Rocher et al. 2004), are generally attributed to a higher specific surface area of particles and/or to the presence of organic matter. In our case, as will be shown below, the enhancement of heavy metal content in fraction I results from the nature of heavy metalbearing species, mainly generated by erosive wear of materials and by precipitation of neoformed species.

The comparison of our sediment heavy metal loads with literature data appears rather difficult: first, the definition of sewer sediment size fractions is rather variable, e.g. unfractioned in Michelbach and Wöhrle (1993), or less and greater than $400 \mu \mathrm{m}$ in Rocher et al. (2004). Then, the sediment metal content may depend on the type of sewer system, separate or combined, and in the latter case, on the local urban watershed characteristics (roofing materials, daily traffic volume,...). In this study, three sediments samples were taken from the separate sewer system. It is then not surprising that our samples show much lesser lead and zinc concentrations than those measured by Gromaire et al. (2001) in the 'Marais' experimental site (Paris), since $80 \%$ of $\mathrm{Pb}$ and $\mathrm{Zn}$ loads were attributed to roof runoff collected in the combined sewer.

Preliminary information about the nature of heavy metal-bearing particles may be obtained by seeking eventual correlations between the metal contents of various compartments. Thus, the linear relationship between $\mathrm{Ni}$ and $\mathrm{Cr}$ with the characteristic 8/18 slope (fig. 2a), suggests that these two elements are essentially present as stainless steel of the type used for kitchen appliances. On the other hand, the slope of the iron-chromium correlation can not be related to any alloy composition, and hence likely indicates that those 
two elements are released in the sewer system in given proportions (inset of fig. 2a). Sewer sediments also show a good correlation between $\mathrm{Zn}$ and phosphorus contents (fig. 2b). Although solubility calculations imply that sewage is supersaturated with regard to $\mathrm{Zn}_{3}\left(\mathrm{PO}_{4}\right)_{2}$, the rather low value of the slope suggests that zinc is entrapped within phosphate mineral species that accumulate in sewer sediments (Houhou et al. 2009).

\subsection{Nature of mineral species and heavy metal-bearing species in the sewer system.}

3.2.1 X-ray diffraction results. X-ray diffraction analyses reveal that quartz (peaks at 3.34, 4.28, and $2.29 \AA$ ), calcite (peaks at 3.05 and $1.92 \AA$ ), and feldspars (peaks at 3.21 and 3.26 $\AA$ ), are the main crystalline minerals in sewer sediments (fig. 3). The mineral assemblage of sediments - either taken from combined or separate sewers - was relatively uniform, with reflections of quartz slightly more intense in the coarse fraction, and with small amounts of kaolinite identified in the $<50 \mu \mathrm{m}$ fraction. Weak reflections of quartz, calcite, and the (001)

peak of smectite located at $14 \AA$, were also detected in suspended solids, the signal-to-noise ratio indicating that amorphous material dominates those samples. Such X-ray diffractograms likely provide a fingerprint of some domestic activities: thus, feldspars, calcite, and quartz can be found in household cleaners, whereas calcite is a major ingredient in toothpaste, and smectite is commonly encountered in cosmetics and drugs (Castela-Papin et al., 1999).

3.2.2 Heavy metal-bearing species in suspended solids. A total of 1330 mineral particles from sewage suspended solids was examined by electron microscopy over the course of this study. The main classes of heavy metal-bearing particles were sulfides (11.5\%), alloys (9.6\%), oxides $(7.9 \%)$, calcium phosphates $(3.9 \%)$, sulfates $(2.1 \%)$, metal particles $(1.8 \%)$, whereas other minor forms include carbonates (e.g. $\mathrm{ZnCO}_{3}$ ) and hydroxides. The percentages given above are based on SEM imaging with back-scattered electrons. The particles made of light elements are then largely underestimated in the calculation of relative abundances, even though those particles, i.e. zeolites, clay minerals (talc, montmorillonite, kaolinite, muscovite, illite), feldspars (albite and microcline), calcite and dolomite, amorphous silica,... do not contain heavy metals with respect to the detection limit of EDXS.

Figure 4 shows electron micrographs of typical heavy metal-bearing particles found in sewage. Various metal sulfides were identified: chalcocite $\left(\mathrm{Cu}_{2} \mathrm{~S}\right)$ (fig. $\left.4 \mathrm{a}\right)$, covellite $(\mathrm{CuS})$, and copper sulfides with intermediate $\mathrm{Cu} / \mathrm{S}$ ratios that might be agglomerates of the two previous mineral species (fig. 4b), were commonly encountered as precipitates of micron-size 
elementary particles. Sphalerite $(\mathrm{ZnS})$ occurred both as isolated granular phases with average diameters around $0.4 \mu \mathrm{m}$ (Fig. $4 \mathrm{c}$ ), and as small grains formed on barite surfaces $\left(\mathrm{BaSO}_{4}\right)$. Other sulfide phases such as mackinawite $(\mathrm{FeS})$, pyrite $\left(\mathrm{FeS}_{2}\right)$, millerite $(\mathrm{NiS})$, argentite $\left(\mathrm{Ag}_{2} \mathrm{~S}\right)$, and chalcopyrite $\left(\mathrm{CuFeS}_{2}\right)$, were determined occasionally. Even more anecdoctical, a few particles that display EDX spectra with complex compositions of $\mathrm{Hg}, \mathrm{Ag}, \mathrm{Cu}, \mathrm{Sn}$, and $\mathrm{S}$, were interpreted as fragments of dental amalgams in view of their agglomerated aspect (Acciari et al. 2001).

As previously reported by El Samrani et al. (2004), such sulfide phases correspond to neoformed mineral species: in the sewer system, sulfide is primarily produced by sulfatereducing bacteria under anaerobic conditions (Nielsen et al. 1998; Zhang et al. 2008); it may subsequently react with dissolved metal ions to form metal sulfide precipitates (Herbert et al. 1998; Jong and Parry 2003). Such a reaction pathway has been widely used to control $\mathrm{H}_{2} \mathrm{~S}$ emission in sewer networks (Padival et al. 1995), and to bioremediate heavy metal pollution in anoxic aquatic systems (Neculita et al. 2008). However, the mean content of dissolved oxygen in our sewage samples $(4.1 \pm 3.3 \mathrm{mg} / \mathrm{L})$ and the average sulfate concentration $(95.5 \pm$ $32.6 \mathrm{mg} / \mathrm{L}$ ), suggest that Grand Nancy sewage is generally transported under oxic conditions. Furthermore, the enumeration of sulfate-reducing-bacteria using the most-probable-number technique, indicates that the concentration of such bacteria remains rather limited in sewage with counts lower that 4000 per mL (Houhou et al. submitted). Therefore, the metal sulfides found in suspended solids were obviously precipitated at other locations in the sewer system.

In contrast, the various phosphate phases (brushite, whitlockite, octacalcium phosphate, apatite,...) that were found to entrap $\mathrm{Zn}$ in their lattice have been shown to be formed within the sewage (Houhou et al. 2009). EDX microanalyses reveal a $\mathrm{Zn}$ content of about $0.1 \%$ wt independently of $\mathrm{Ca} / \mathrm{P}$ ratio, which fully agrees with the slope value of $\mathrm{Zn}-\mathrm{P}$ correlation observed for sewer sediments (fig. 2b). Nancy wastewater was also found to be supersatured with respect to barite $\left(\mathrm{BaSO}_{4}\right)$ (Houhou et al. submitted), which explains the frequent observation of this mineral in suspended solids. A single occurrence of chalcanthite $\left(\mathrm{CuSO}_{4} \cdot 5 \mathrm{H}_{2} \mathrm{O}\right)$ was identified although solubility calculations predict that this species normally dissociates in sewage.

Metal oxides, such as iron oxides (wustite $(\mathrm{FeO})$, hematite $\left(\mathrm{Fe}_{2} \mathrm{O}_{3}\right)$, magnetite $\left(\mathrm{Fe}_{3} \mathrm{O}_{4}\right)$, and goethite $(\mathrm{FeOOH}))$, zincite $(\mathrm{ZnO})$ and titanium oxide $\left(\mathrm{TiO}_{2}\right.$ and $\left.\mathrm{Ti}_{2} \mathrm{O}_{3}\right)$, were frequently observed as micron-size particles in suspended solids. These minerals are widely used as pigments in personal-care products (Nohynek et al., 2008), and tattoo inks. About one fourth of iron oxides contained various heavy metals such as $\mathrm{Zn}(0.1-8.4 \%), \mathrm{Cu}(0.2 \%), \mathrm{Cd}(1.1-$ 
$1.6 \%)$ and $\mathrm{Cr}(0.13-0.17 \%)$. Occurrences of nickel oxide (NiO), Rare earth containing oxides such as $\mathrm{La}-\mathrm{Ce}-\mathrm{Fe}$ oxide, and lead oxides $\left(\mathrm{PbO}\right.$ and $\left.\mathrm{PbO}_{2}\right)$ that may originate from lead pipe scales (Reuter et al. 2005) or from lead stabilisers in PVC pipes, were also determined.

Various metal alloys such as typical stainless steel (FeCrNi and FeCrMn) were frequently evidenced in sewage suspended solids. Additional elements that were found in stainless steel, include $\mathrm{Sb}(3.3 \%)$ often added in kitchenware to increase its hardness (Tsujikawa et al. 2007), and Sn (3\%) that is plated over steel in food cans. If FeCr particles with $\mathrm{Cr}$ contents ranging from 5.7 to $11.3 \%$ probably identify fragments of commercial razor blade, and if SnSb alloys ( $\mathrm{Sn} 25.4 \%$ and $\mathrm{Sb} 17.4 \%$ ) may be associated with high temperature welding (Chen et al., 2008), most binary alloys such as FeNi (Ni 21.8\%), FeCu with $\mathrm{Cu}$ contents ranging between $1.5 \%$ and $5.7 \%$, and $\mathrm{CuAl}$ with $4.1 \%$ of $\mathrm{Cu}$ (aluminium bronze), could not be related to their corresponding domestic use.

Micron-size copper metallic particles (fig. 4d) and solder alloys containing $\mathrm{Pb}$ and $\mathrm{Sn}$ found in separate-sewer portions, were attributed to the internal corrosion of domestic plumbing system. Indeed, SEM-EDX analyses of particles retained onto $0.2 \mu \mathrm{m}$ pore-size membranes after tap-water filtration, show that the drinking water system is a potential source of some heavy metal-bearing particles found in sewage. Oxidized phases such as tenorite $(\mathrm{CuO})$ and cuprite $\left(\mathrm{Cu}_{2} \mathrm{O}\right)$ known to play a major role in copper pipe corrosion (Merkel et al. 2002), cassiterite $\left(\mathrm{SnO}_{2}\right)$, ill-defined oxidized phases containing heavy metals ( $\mathrm{Pb}(1.9-2.6 \%)$, $\mathrm{Cu}(2.1-16.7 \%), \mathrm{Zn}(0-0.5 \%), \mathrm{Sn}(0-24.4 \%)$ and $\mathrm{Fe}(0-10.2 \%))$, assumed to be corroded soldering material (fig. 4e), and iron oxides or oxihydroxydes with traces of $\mathrm{Pb}(0.5-5 \%), \mathrm{Zn}$ $(0.5-1.8 \%), \mathrm{Cu}(1-3 \%)$ and $\mathrm{Ni}(0.25 \%)$, represent about two third of identified minerals. Other corrosion by-products determined from EDX spectra include usual scale constituents such as malachite $\left(\mathrm{CuCO}_{3} \cdot \mathrm{Cu}(\mathrm{OH})_{2}\right)$ (e.g. Merkel et al. 2002), well-crystallized hydrocerussite $\left(\mathrm{Pb}_{3}\left(\mathrm{CO}_{3}\right)_{2}(\mathrm{OH})_{2}\right)$ (fig. 4f) (e.g. Reuter et al. 2005), smithsonite $\left(\mathrm{ZnCO}_{3}\right)$ (inset of fig. 3f), and ankerite $\left(\mathrm{CaFe}\left(\mathrm{CO}_{3}\right)_{2}\right)$ containing traces of $\mathrm{Cu}(0.35 \%), \mathrm{Pb}(0.1 \%)$ and $\mathrm{Zn}(0.1 \%)$. Unlike oxidized phases, the carbonate species were exceptionnally found in sewage suspended solids. A few occurrences of copper metal (inset of fig. $4 \mathrm{~d})$ and of chrysocolla $\left(\mathrm{CuSiO}_{3}\right)$ were also evidenced.

3.2.3 Heavy metal-bearing species in sewer sediments. Sewer sediments $(<50 \mu \mathrm{m}$ fraction and bromoform-separated 50-250 $\mu \mathrm{m}$ and $250 \mu \mathrm{m}-2 \mathrm{~mm}$ concentrates) were found to be substantially enriched in sulfide minerals (37\% of heavy metal carriers), although various metal oxides $\left(\mathrm{ZnO}_{2}, \mathrm{PbO}_{2}, \mathrm{TiO}, \mathrm{TiO}_{2}, \mathrm{Ti}_{2} \mathrm{O}_{3}\right)$, silicates $\left(\mathrm{PbSiO}_{4}, \mathrm{ZrSiO}_{4}\right)$, and numerous 
stainless steel fragments were also evidenced. Moreover, most metal oxides and alloys were partially sulfurized with a sulfur content ranging between 0.4 to $13.2 \%$. As in suspended solids, the sulfide species identified in sewer sediment display a wide compositional variability. Iron sulfides occurred as pyrite $\left(\mathrm{FeS}_{2}\right)$, greigite $\left(\mathrm{Fe}_{3} \mathrm{~S}_{4}\right)$ and mackinawite $(\mathrm{FeS})$. Mackinawite was generally observed as relatively large $(20 \mu \mathrm{m})$ crystallized textured particles (fig. 5a), with traces of $\mathrm{Zn}(1.21 \%)$ and $\mathrm{Cu}(0.45 \%)$. Such observation is consistent with previous literature describing mackinawite as a potential sink for heavy metal during early diagenesis in anoxic sediments (Morse and Arakaki 1993). Lead occurred under both oxidized $(\mathrm{PbO})$ and sulfurized $(\mathrm{PbS})$ species, these two species being either found as individual or mixed particles. Zinc was mainly present as sphalerite $(\mathrm{ZnS})$, but a $\mathrm{Zn}_{2} \mathrm{~S}$ species under the form of $0.4 \mu \mathrm{m}$ nanoclusters was also identified. To our knowledge, the latter species has only been described in thin films prepared by sputtering methods (Matsuoka et al. 1988). Bismuth sulfides (fig. 5 b) of various stoichiometries $\left(\mathrm{BiS}_{2}, \mathrm{Bi}_{2} \mathrm{~S}_{3}\right.$ (bismuthinite), and $\mathrm{Bi}_{3} \mathrm{~S}_{4}$ ) were also determined in sewer sediments after a gastroenteritis outbreak in the fall of 2004, which suggests that bismuth-based medication was prescribed at that time.

Copper was mainly present as covellite $(\mathrm{CuS})$ and 15 to $150 \mu \mathrm{m}$ mixed $\mathrm{Cu}-\mathrm{Fe}$ sulfides. Interestingly, similar $\mathrm{Cu}-\mathrm{Fe}$ sulfide minerals have been described in anaerobic river sediments impacted by wastewater discharges (Sutherland et al. 2007; Marcussen et al. 2008). Detailed investigations of the texture of mixed $\mathrm{Cu}-\mathrm{Fe}$ sulfide species revealed significant differences between particles and sometimes within one particle. As an illustration, figure $5 \mathrm{c}$ shows a $\mathrm{Cu}-$ Fe-S particle with a very heterogeneous surface that appears to be divided into an inner amorphous region and an outer crystalline layer (inset Fig. 5c). The local EDX spectrum of the inner region indicates a $\mathrm{Cu}_{4} \mathrm{FeS}_{4}$ stoechiometry, whereas the composition of the outer crystalline material corresponds to $\mathrm{CuS}$, i.e. covellite whose typical crystal habitus can be recognized in the inset figure $5 \mathrm{c}$. Such an organization suggests that successive stages of sulfide mineralization have occurred within the sewer system.

Actually, close examination of most individual sulfide particles indicates that the nature of those mineral phases has evolved in the sewer system. Figure $5 \mathrm{~d}$ shows a $\mathrm{PbS}$ sulfide that displays a fine-banded fibrous structure, thus indicating significant chemical changes in the growth history of this mineral. Likewise, the greigite particles found in sewer sediments likely result from the oxidation of mackinawite (Lennie et al. 1997); this may occur during anoxic/oxic sequences associated with episodes of resuspension, transportation, and sedimentation, in the sewer environment (Hilton 1990). The formation of sphalerite grains on barite surfaces (fig. 5e), may involve both sulfate-reducing bacteria using $\mathrm{BaSO}_{4}$ as a sulfate 
source for anaerobic respiration (Baldi et al. 1996), and a subsequent precipitation of Znsulfide coating. Finally, partially sulfurized metal alloy such as the $\mathrm{Sn}-\mathrm{Pb}-\mathrm{Fe}-\mathrm{Cu}-\mathrm{Zn}$ particle shown in fig. 5f, necessarily implies a complex evolution of that particle, as EDX microanalyses reveal the simultaneous coexistence of lead oxide, unaltered $\mathrm{Sn}-\mathrm{Pb}-\mathrm{Fe}-\mathrm{Cu}$ alloy, $\mathrm{SnSO}_{4}$, and $\mathrm{PbS}$.

3.2.4 Determining the location of sulfide mineral production. If part of the history recorded in the texture of sulfide minerals and partially sulfurized particles certainly occurs within sewer deposits, the formation of metal sulfides may be initiated at other places within the sewer environment. Bacterial biofilms have been shown to be major sites for dissolved sulfide production, and hence for metal sulfides accumulation (e.g. Nielsen et al. 2005). However, the vast majority of particles characterized by TEM-EDXS and SEM-EDXS in sewer biofilms (about 480), were similar to those described in sewage suspended solids, and, in consequence, may have simply been entrapped in the organic matrix. Thus, metal sulfides represented only $12 \%$ of analyzed particles, and as illustrated in fig. $6 \mathrm{a}$, most of them could have been found in sewer sediments. Still, the sulfur content of numerous alloys found in sewer biofilms (1-10\%) (fig. 6b), the dendritic appearance of some sulfides - e.g. the pyrite particle shown in fig. 6c suggest that a fraction of sulfide minerals has probably been neoformed within the biofilm. Another microbially-mediated process observed in the sewer biofilm is the corrosion of iron oxide particles. Fig. $6 \mathrm{~d}$ shows etch pits on an iron oxide surface which can be associated with bacteria-promoted dissolution; the bacteria can be seen behind and within those tunnels (inset Fig. 6d). A similar corrosion pattern has been documented by Mustin et al. (1992) for pyrite biolixiviation with Thiobacillus ferrooxidans.

Actually, the very first place where anaerobic conditions can be encountered in the sewer system, is the washbasin siphon. If amorphous silica and corundum $\left(\mathrm{Al}_{2} \mathrm{O}_{3}\right)$ were the dominant particles in siphon deposits (15 to $78 \%$ of analyzed particles), $\mathrm{CuO}, \mathrm{Zn}$-containing iron oxyhydroxydes, $\mathrm{PbO}, \mathrm{PbO}_{2}, \mathrm{TiO}_{2}$, and $\mathrm{Ti}_{2} \mathrm{O}_{3}$, were also frequently determined. Those mineral species correspond to suspended particles found in tap water, pigments from personal-care products, and abrasives from household cleaners and soap. Two types of sulfides were also observed: (i) chalcocite $\left(\mathrm{Cu}_{2} \mathrm{~S}\right)$ and covellite $(\mathrm{CuS})$ identified as aggregates of about $0.1 \mu \mathrm{m}$ elementary units (fig. 7a-b), electron diffraction patterns confirming the crystallized nature of those particles; such aggregates are reminiscent of most copper sulfides identified in sewage which can then be assigned to resuspended particles from washbasin siphons. (ii) Sulfides of $\mathrm{Cu}, \mathrm{Zn}, \mathrm{Pb}$, and $\mathrm{Sn}$, found homogeneously precipitated on the surface 
of bacteria (see scanning-TEM-EDXS elemental mapping in fig. 7c-d). Such microbiallymediated sulfide precipitation has already been documented in marine and freshwater environments (Degens and Ittekkot 1982; Ferris et al. 1987). Obviously, sulfide formation starts early in the sewer system, though the small size of sulfide minerals observed in washbasin siphons as well as their dominant monosulfide character, does not identify most sulfide species found in sewer sediments or biofilms.

The mineralogy of sump pit deposits was also examined. $85 \%$ of the particles observed by SEM backscatter imaging contained sulfur. This strong enrichment in sulfur is well illustrated by the case of heavy metal carbonates such as $\mathrm{PbCO}_{3}$ and $\mathrm{ZnCO}_{3}$ originating from the erosion of domestic plumbing, which were found coated with $\mathrm{PbS}$ and $\mathrm{ZnS}$ (Fig. 8a). Likewise, almost all particles containing chalcophile elements (alloys, copper fragments, and dental amalgams) were sulfurized. Many of the heavy metal sulfides identified in sewer sediments and sewage suspended matter $\left(\mathrm{CuS}, \mathrm{Cu}_{2} \mathrm{~S}, \mathrm{ZnS}, \mathrm{FeS}, \mathrm{FeS}_{2}, \mathrm{PbS}, \mathrm{ZnS}\right)$ were also found in sump pits deposits. Sulfides showed either dendritic directional growth (e.g. chalcocite in fig. 8b) or well-crystallized structure (e.g. cubic galena exhibiting growth steps in fig. 8c). Mixed $\mathrm{Cu}-\mathrm{Fe}$ sulfides with an outer layer of well-crystallized $\mathrm{CuS}$ were also observed (fig. 8d).

Eventually, sump pits, and more generally household connections to the sewer system, appear to be major sites for either metal sulfurization or sulfide formation. Indeed, the high organic load contained in sewage combined with the intermittent flow regime characteristic of the domestic drainage system, imply rapid anaerobic conditions and enhanced activity of sulfate-reducing bacteria in the remaining stagnant wastewater. The sulfurized material may then be eroded, resuspended, and transported within the sewer system, where it can settle depending on flow conditions, and once settled, undergo additional sulfurization cycles.

\section{CONCLUSION}

This study provides information on the levels of metal pollutants transported in the sewer system with a focus on the minerological characteristics of heavy metal-bearing particulate phases encountered both at the household scale (washbasin siphon and sump pit deposits) as well as at the sewer trunk scale (suspended solids, sediments, and biofilms). Chemical analyses of soluble heavy metals indicate that (i) domestic plumbing is an important source of $\mathrm{Cu}$ in wastewater, (ii) dissolved $\mathrm{Zn}$ and $\mathrm{Pb}$ mainly originate from household activities, (iii) multiple inputs including groundwater infiltration can be distinguished for $\mathrm{Ni}$, 
$\mathrm{Cr}$, and $\mathrm{Cd}$. Still, the mean total concentrations of $\mathrm{Cu}, \mathrm{Zn}, \mathrm{Pb}, \mathrm{Ni}$, and $\mathrm{Cr}$, in domestic sewage were found to be very similar to those measured in other developed cities over the world.

Even though the number of heavy metal-bearing particles observed by electron microscopy in our study remains infinitesimally small compared to the total amount of particles transported in sewer systems, our results suggest that (i) tap water contributes to the particulate load in sewage due to the corrosion of water supply pipes, (ii) in the sewer system, metals are mainly encountered as alloys, oxidized, and sulfurized phases, (iii) the sulfurization of alloys and the precipitation of sulfide species start in deposits located in washbasin siphons and in household connections to the sewer trunks, (iv) most sulfide phases observed in sewage suspended solids originate from the erosion of those deposits and from the detachment of biofilms, and these species accumulate in sewer sediments, (v) phosphates phases neoformed in the sewer system is also a significant sink for $\mathrm{Zn}$. This study is a first step towards a better understanding of heavy metal cycling in the sewer system.

Acknowledgements : This study was mainly supported by a grant from CNRS-INSU (ECODYN). Lorraine Region also provided part of the funding through Zone Atelier Moselle. We are grateful to M. Piqué and M. Villeroy (Service hydraulique CUGN) for logistical support during all field studies. We also wish to thank the staff of SARM (CRPG-UPR 80) where chemical analyses were carried out.

\section{REFERENCES}

Acciari, H.A., Guastaldi, A.C., Brett C.M.A. (2001) Corrosion of dental amalgams: electrochemical study of $\mathrm{Ag}-\mathrm{Hg}, \mathrm{Ag}-\mathrm{Sn}$ and $\mathrm{Sn}-\mathrm{Hg}$ phases. Electrochim. Acta. 46, 38873893.

Aonghusa, C.N., Gray, N.F. (2002) Laundry detergents as a source of heavy metals in Irish domestic wastewater. J. Environ. Sci. Health A Tox. Hazard. Subst. Environ. Eng. 37(1), 1-6.

Ashley, R.M., Fraser, A., Burrows, R., Blanksby, J. (2000) The management of sediment in combined sewers. Urban Water 2(4), 263-275.

Baldi, F., Pepi, M., Burrini, D., Kniewald, G., Scali, D., Lanciotti, E. (1996) Dissolution of barium from barite in sewage sludges and cultures of Desulfovibrio desulfuricans. Appl. Environ. Microbiol. 62(7), 2398-2404.

Balmer, P. (2001) Possibilities to improve the quality of wastewater sludges. Wat. Sci. \& Technol. 44(10), 19-26. 
Boller, M. (1997) Tracking heavy metals reveals sustainability deficits of urban drainage systems. Wat. Sci. Technol. 35(9), 77-87.

Carignan, J., Hild, P., Mevelle, G., Morel, J., Yeghicheyan, D. (2001) Routine analysis of trace elements in geological samples using flow injection and low pressure on-line liquid chromatography coupled to ICP-MS: a study of geochemical reference materials BR, DR-N, UB-N, AN-G, and GH. Geostandards Newsletter 25, 187-198.

Castela-Papin, N., Cai, S., Vatier, J., Keller, F., Souleau, C.H., Farinotti, R. (1999) Drug interactions with diosmectite: astudy using the artificial stomach-duodenum model. Int. J. Pharm. 182, 111-119.

Chebbo, G., Gromaire, M.C., Ahyerre, M., Garnaud, S. (2001) Production and transport of urban wet weather pollution in combined sewer systems: the "Marais" experimental urban catchment in Paris. Urban Water. 3, 3-15.

Chen, S-W., Zi, A-R., Chen, P-Y., Wu, H-J., Chen, Y-K., Wang, C-H. (2008) Interfacial reactions in the $\mathrm{Sn}-\mathrm{Sb} / \mathrm{Ag}$ and $\mathrm{Sn}-\mathrm{Sb} / \mathrm{Cu}$ couples. Mater. Chem. Phys. 111, 17-19.

Comber, S.D.W. and Gunn, A.M. (1996) Heavy metals entering sewage-treatment works from domestic sources. J. CIWEM, 10, 137-142.

Chino, M. Moriyama, K., Saito, H., Mori, T. (1991) The amount of heavy metals derived from domestic sources in Japan. Water, Air, and Soil Pollution 57-58, 829-837.

Degens E.T. and Ittekkot IV (1982) In situ metal staining of biological membranes in sediments. Nature 298, 262-264.

El Samrani, A.G., Lartiges, B.S., Ghanbaja, J., Yvon, J., Kohler, A. (2004) Trace element carriers in combined sewer during dry and wet weather: an electron microscope investigation. Water Res. 38, 2063-2076.

El Samrani, A.G., Lartiges, B.S., Villieras F. (2008) Chemical coagulation of combined sewer overflow: Heavy metal removal and treatment optimization. Wat. Res. 42(4-5), 951-960.

Ferris F.G., Fyfe, W.S., Beveridge T.J. (1987) Bacteria as nucleation sites for authigenic minerals in a metal contaminated lake sediment. Chem. Geol. 63, 225-232.

Francis, A.J., Dodge, C.J. (1986) Anaerobic bacterial dissolution of lead oxide. Arch. Environ. Contam. Toxicol. 15, 611-616.

Gasperi, J., Garnaud, S., Rocher, V., Moilleron, R., (2008) Priority pollutants in wastewater and combined sewer overflow. Sci. Total Environ. 407, 263-272.

Grabtree, R.W. (1989) Sediments in sewers. J. Inst. Water Environ. Manage. 3, 569-578.

Gray, S.R., Becker, N.S.C. (2002) Contaminant flows in urban residential water systems. Urban water. 4, 331-346. 
Gray, S.R., Becker, N.S.C. (2002) Contaminant flows in urban residential water systems. Urban Water 4, 331-346.

Gromaire, M.C., Garnaud S., Saad, M., Chebbo, G. (2001) Contribution of different sources to the pollution of wet weather flows in combined sewers. Water Res. 35(2), 521-533.

Grosjean, E., Adam, P., Connan, J., Albrecht, P. (2004) Effects of weathering on nickel and vanadyl porphyrins of a lower Toarcian shale of the Paris basin. Geochim. Cosmochim. Acta 68(4), 789-804.

Herbert Jr., R.B., Benner, S.G., Pratt, A.R., Blowes D.W. (1998) Surface chemistry and morphology of poorly crystalline iron sulfides precipitated in media containing sulfatereducing bacteria. Chem. Geol. 144, 87-97.

Hilton, J. (1990) Greigite and the magnetic properties of sediments. Limnol. Oceanogr. 35, 509-520.

Houhou, J., Lartiges, B.S., Hofmann, A., Frappier, G., Ghanbaja, J., Temgoua, A. (2009) Phosphate dynamics in an urban sewer: a case study of Nancy, France. Wat. Res. 43(4), 10881100 .

Houhou, J., Lartiges, B.S., France-Lanord, C., Guilmette, C., Poix, S., Mustin, C. (2009) Isotopic tracing of clear water sources in an urban sewer: a combined water and dissolved sulfate stable isotopes approach. Wat. Res. (submitted).

Jong, T., Parry, D.L. (2003) Removal of sulfate and heavy metals by sulfate reducing bacteria in short-term bench scale upflow anaerobic packed bed reactor runs. Water Res. 37, 33793389 .

Lennie, A., Redfern, S., Champness, P., Stoddart, C., Schofield, P., Vaughan, D. (1997) Transformation of mackinawite to greigite: an in situ X-ray powder diffraction and transmission electron microscopy study. Am. Mineral. 82, 302-309.

Marcussen, H., Dalsgaard, A., Holm, P.E. (2008) Content, distribution and fate of 33 elements in sediments of rivers receiving wastewater in Hanoi, Vietnam. Environ. Pollut. 155, 41-51.

Matsuoka, T., Kuwata, J., Nishikawa, M., Fujita, Y., Tohda, T., Abe, A. (1988) A study of the crystallographic and luminescent characteristics of $\mathrm{ZnS}: \mathrm{Mn}$ films prepared by an RF Magnetron sputtering method for AC thin-film electroluminescent devices. Jpn. J. Appl. Phys. 27, 592-596.

Merkel, T.H., Groß, H-J., Werner, W., Dahlke, T., Reicherter, S., Beuchle, G., Eberle, S.H. (2002) Copper corrosion by-product release in long-term stagnation experiments. Water Res. $36,1547-1555$.

Michelbach S., Wöhrle, C. (1993) Settleable solids in a combined sewer system, settling characteristics, heavy metals, efficiency of storm water tanks. Wat. Sci. Technol. 27 (5-6), 153-164. 
Morse, J.W., Arakaki, T. (1993) Adsoption and coprecipitation of divalent metals with mackinawite (FeS). Geochim. Cosmochim. Ac. 57(15), 3635-3640.

Mustin, C., Berthelin, J., Marion, P., de Donato, P., (1992) Corrosion and electrochemical oxidation of a pyrite by Thiobacillus ferrooxidans. Appl. Environ. Microbiol. 58(4), 11751182.

Neal, A.L., Techkarnjanaruk, S., Dohnalkova, A., McCready, D., Peyton, B.M., Geesey, G.G. (2001) Iron sulfides and sulfur species produced at hematite surfaces in the presence of sulfate-reducing bacteria. Geochim. Cosmochim. Ac. 65(2), 223-235.

Nielsen, A.H., Lens, P., Hvitved-Jacobsen, T., Vollertsen, J. (2005) Effects of aerobicanaerobic transient conditions on sulfur and metal cycles in sewer biofilms. Biofilms 2(2), 8191.

Nielsen, P.H., Raunkjær, Hvivtved-Jacobsen, T. (1998) Sulfide production and wastewater quality in pressure mains. Wat. Sci. Technol. 37(1), 97-104.

Nohynek, G.J., Dufour, E.K., Roberts, M.S. (2008) Nanotechnology, cosmetics and the skin: is there a health risk? Skin Pharmacol. Physiom. 21(3), 136-149.

Neculita, C.M., Zagury, G.J. (2008) Biological treatment of highly contaminated acid mine drainage in batch reactors: Long-term treatment and reactive mixture characterization. J. Hazard. Mater. 157(2-3), 358-366.

Oskarsson, A. and Norrgren, L. (1998) Copper pipes as a source of copper exposure in man and environment. Environ. Rev. 6, 139-150.

Padival, N.A., Kimbell, W.A., Redner, J.A. (1995) Use of iron salts to control dissolved sulfide in trunk sewers. J. Environ. Engng. 121, 824-829.

Palmquist, H., Hanaeus, J. (2005) Hazardous substances in separately collected grey- and blackwater from ordinary Swedish households. Sci. Total Environ. 348, 151-163.

Reuter, C, Conway, J.I., Gerke, T.L., Mast, D.B., Maynard, J. (2005) The mineralogy of Pb scales in drinking water distribution systems as revealed by combined XRD and micro-Raman spectroscopy. Abstracts with programs. Geological Society of America, vol 35, N5, p.34.

Rocher, V., Azimi, S., Moilleron, R., Chebbo, G. (2004) Hydrocarbons and heavy metals in the different sewer deposits in the 'Le Marais' catchment (Paris, France): stocks, distributions and origins. Sci. Total Environ. 323, 107-122.

Rule, K.L., Comber, S.D.W., Ross, D., Thornton, A., Makropoulos, C.K., Rautiu, R. (2006) Diffuse sources of heavy metals entering an urban wastewater catchment. Chemosphere. 63, 64-72.

Singh, R.P., Agrawal, M. (2008) Potential benefits and risks of land application of sewage sludge. Waste Management 28(2), 347-358. 
Sörme, L., Lagerkvist, R. (2002) Sources of heavy metals in urban wastewater in Stockholm. Sc. Total Environ. 298, 131-145.

Soonthornnonda, P. and Christensen, E.R. (2008) Source apportionment of pollutants and flows of combined sewer wastewater. Wat. Res. 42, 1989-1998.

Sutherland, T.F., Petersen, S.A., Levings, C.D., Martin, A.J. (2007) Distinguishing between natural and aquaculture-derived sediment concentrations of heavy metals in the Broughton Archipelago, British Columbia. Mar. Pollut. Bull. 54, 1451-1460.

Tamasi, G., Cini, R. (2004) Heavy metals in drinking waters from Mount Amiata (Tuscany, Italy). Possible risks from arsenic for public health in the Province of Seina. Sci. Total Environ. 327, 41-51.

Tsuji-Naito, K., Hatani, T., Okada, T., Tehara, T. (2007) Modulating effects of a novel skinlightening agent, $\alpha$-lipoic acid derivative, on melanin production by the formation of DOPA conjugative products. Bioorgan. Med. Chem. 15, 1967-1975.

Tsujikawa, M., Noguchi, S., Yamauchi, N., Ueda, N., Sone, T. (2007) Effect of molybdenum on hardness of low-temperature plasma carburized austenitic stainless steel. Surf. Coat. Tech. 201, 5102-5107.

Vollertsen, J., Hvitved-Jacobsen, T. (2000) Resuspension and oxygen uptake of sediments in combined sewers. Urban Water. 2, 21-27.

Wilkie, P.J., Hatzimhalis, G., Koutoufides, P., Connor, M.A. (1996) The contribution of domestic sources to levels of key organic and inorganic pollutants in sewage: The case of Melbourne, Australia, Wat. Sci. Technol, 34(3-4), 63-70.

Zhang, L., De Schryver, P., De Gusseme, B., De Muynck, W., Boon, N., Verstraete, W. (2008) Chemical and biological technologies for hydrogen sulfide emission control in sewer systems: A review. Water Res. 42, 1-12. 